caput sucsedaneum, which is always found on the side which has been next the pubes, the shoulders were reversed no fewer than sixteen times; that is, where the right ear had been next the pubes, the left shoulder came to the arch, and conversely. Nägele, indeed, says that sometimes with roomy pelves he has observed the shoulders entirely expelled with their greatest breadth in the transverse diameter, * that is, without either shoulder coming to the arch ; but he alludes to no other deviation from the rule usually laid down. In my cases, the head twisted round soon after its expulsion, and the wrong shoulder came distinctly to the arch, not only in easy cases, but in some very hard ones. I need only mention one where I could not be deceived. In the early part of the labour I had felt the anterior fontanelle near the left acetabuluin. 'The labour went on very slowly, though the puins were severe. The anterior fontanelle approached nearer the pubes. Thinking the labour was likely to be very protracted, I applied the long forceps, and with some trouble brought away the head. Just before expulsion, I felt the anterior fontanelle under the arch close to the left side of the symphysis. I found after birth the marks of the forceps. one on the right temple in front of the ear, the other on the side of the neck under and rather behind the left ear. My diagnosis was thus confirmed, by finding that the left side of the head had been the lowest, and consequently next the pubes in the first stage. But even in this case the right shoulder came to the pubes, and it required considerable traction to dritw away the trunk, the child being a very large one. As I have been somewhat curious on this point, I have always been particularly cireful after the birth of the head to allow the shoulders to take their own direction.

As I have given a hard ciuse where the shoulders were reversel, I may as well add from my notes, written at the time, an example of an easy one, where the same phenomenon was observel. This case was one which occurred before January 18.j.2, and is not included among the sixteen already referred to.

“No. 1846, December 13th, 18.jl. Anterior fontanelle felt near pubes, very close to it. Head quite disposed to descend, after rupture of the membranes with well dilated os uteri. Thinking this a case for spontaneous rectification, I contented myself with keeping a finger gently applied during the pains to the fontanelle, that I might accurately observe the changes. The sagittal suture was directed obli juely backwards, and the posterior fontanelle wits felt distinctly near the sacrum, the anterior fontanelle being inclined slightly to the left side. Very rapidly, during one pain the head revolved, the anterior fontanelle passed upwards and to the left side of the pelvis, the posterior descended and passed round to the right side of the pelris, and thence to the arch of the pubes with about two more pains, when it was expelled in the natural position. But the head continued to revolve, and the right shouller passed under the pubic arch instead of the left, and thus the shoulders were expelled with the face turned to the right side of the mother, and the occiput to the left; although, as beforc said, in passing through the pelvis, the occiput was turned to the right side, and the face to the left". (Note in Register.)

In a future paper, I hope to be able to give the results of my observations on those interesting cases, in which, as in the one just quoted, the anterior fontanelle is felt in the first stage near the pubes. I think they can be satisfactorily explained.

Alforl, l.ineolnshire, July 25th, 1853.

" "Dass die schultern mit, ihrer grüssten Breite im Querilurchn'sser

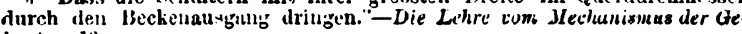
burt, p. 13.

\section{CASE OF IMPERFORATE ANUS, WITH ABSENCE OF THE RECTUM.}

By HENRY DAYMAN, Esq., Surgeon.

(Read before the IIedical Society of Southampton.)

Or the 7 th of March, 1853, I delivered Mrs. M., aged 36, of a fine healthy male child. On the loth, I discovered that the infant was the subject of that peculiar arrest of development to which the term "imperforate anus" has been given. In the present instance, however, the anus was perfect; and within the apparently natural orifice there was a mucous surface, ending about three-fourths of an iuch up in a shut sac. Now, although the prognosis under this peculiar condition is confessedly unfavourable and the prospect from surgical interference most uninviting, yet, in this case it becaure at once evident that something must be done to relieve the pent up meconium. Accordingly I consulted with my friend Mr. Spear, of Eling, on the best plan of proceeding; and we arranged to meet the following day and perforate the sac, with the view of establishing a communication between the gut above and the imperfect rectum.

Mr. Spear and myself met on the next day, the 11th, having delayed our meeting several hours to allow the child to be baptized. Our services were not required for the living; the child had died a few hours before our arrival at the house.

A post mortem examination was at once obtained; and, with the assistance of Mr. Spear, I had the opportunity of waking a thorough and claborate inrestigation of the parts involved in this singular malformation.

The child was large and well formed, of natural colour everywhere, except over the aldoinen, which was black, tense, and swollen, and its walls appeared so attenuated that one might almost iniarine the convolutions of the intestines were visible through the parietes. On openior the abdomen, one immense object presented itself, which seemed to olsccure every other. This was the descending colon, distended with meconium, and closed at its distal end, so that it rested on the bladder anteriurly, and on the iliac fossa and lumbar rertebrie at the sides and behind. No portion of the colon was below the brin of the pelvis; but from it descended to the anal pouch a fibrous cord, which, on closer examination, appeared to be made up of condensed bands of pelvic fascia. I carefully removed the colon, together with the entire contents of the pelvis; and of these I subsequently made a minute dissection, with a view to discorer whether any other, and what structures were implicated.

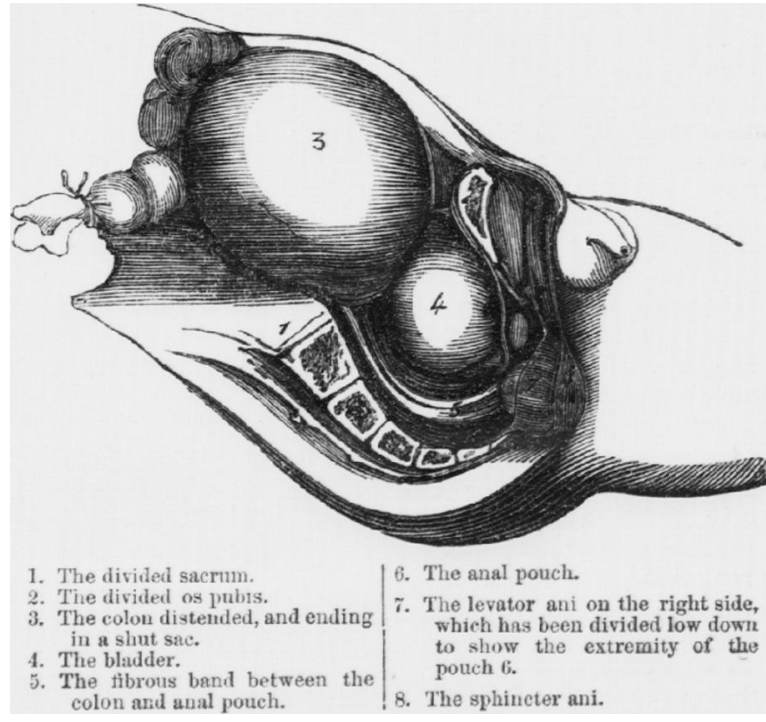

The only peculiarity which I could find was the total absence of the rectum. The fibrous cord which I have mentioned was decidedly not a tube, but was capable throughout its entire length of being split up into fibrous threads 
and was continuous with the pelvic fascia before and behind. It possessed, so far as I could see, no restige of proper muscular tissue; nor did the recto-vesical fold of the peritoneum appear. That membrane, on leaving the fundus of the bladder, was reflected over the enormous colon.

At the anal extremity, the appearances were natural. There was the retraction and puckering of the skin; and on dissecting deeper, the external sphincter was found perfect; but I cannot say that I discovered any circular band of muscle surrounding the pouch, which could be called the internal sphincter. The levatores ani were present and well developed, and together encircled the pouch just within the sphincter.

Milbrook, Southamptou, June $2 \%$ th, $185 \%$.

\section{HINTS ON THE CLIMATE OF ALSTRALIA.}

By w. J. STERLAND, Esq.

[This paper has been communicated to us hy Dr. Cowas, of Reading, who states that the author, though not a member of the medical profession, is entitled to spcak with authority on the climate of Australia. EDIтor.]

THE salubrity of the Australian climate has been so much raunted by almost every writer on the colonies of that vast continent, that it may appear an act of temerity in me to lift up my voice in opposition to the many who have lauded it as the healthiest climate in the world. Yet it is doubtful if these pages would have been written, had not an eminent physician suggested to me, that, having left England for Australia solely on the score of health, my experience of the climate might perhaps be useful to others; and it is on that account alone that I have ventured to pen the following remarks.

Before I set out for Australia, I had been suffering from ill health for some time; and, ere taking the important step of leaviner iny home for the antipodes, I very naturally consulted all the writers on the elimate on whose works I could lay my hands. All (with only one exception) agreed in their accounts of its advantages. The exception was a little work by Dr. Clutterbuck,* a nine years resident in the colony; his statement alone varied from the rest, and he alone painted the climate in the colours which my subsequent experience has found to be correct. I believe his little book met with a good deal of opposition from the advocates of the colony, the writer being described as a disappointed man, who was endeavouring to revenge himself by depreciating the colony on a point which had always been strenuously insisted on as one of its chief advantages. However that might be, I know not; but, so unfavourable was his statement as to the healthiness of the climate, that I studiously kept back this book from some of my friends on this account.

The principal part of Australia that is colonised lies between the 28th and 40th degrees of south latitude, the mean annual heat being about $65^{\circ}$ Fahr. In general, the atmosphere is a brilliant one; the extreme rarity and dryness of the air enabling one to see a far greater distance than is possible in England; indeed, the latter named quality, dryness, I believe to be its great characteristic. During the summer season, when there is a cool air stirring, there is a buoyancy in the atmosphere which I never felt elsewhere. Fren during the rainy winter season, the air possesses the same quality ; it may rain with almost tropical violence, but the air is free from dampness and clamminess; there are no walls streaming with condensed moisture, nor do the clothes steam on approaching the fire, as is so common in this country.

The season of spring commences in September, and is the most delightful part of the year; the ground is covered with an emerald verdure; and, though there are occasional showers, yet the sun shines brightly and cheerily, drying the ground which the heary winter rains have deeply softened; too

* Port Phillip in 1849. By J. B. Clutterbuck, M.D. Loudon: J. W. Parker. much 80, indeed, for the poor pedestrian, but not too much to fertilise the soil. In November, the summer heat commences, and then begins also that bane of the climate, the hot wind.

The interior of the vast continent of Australia, as far as it has been explored by Mitchell, Leichhandt, Sturt, and others, appears to be an interminable waste of sandy and rocky desert. Captain Sturt, who penetrated further to the northward than any other traveller, found himself in a desert of sandy hummocks alternating with bare rocks, and without a trace of vegetation or water. The heat was terrific; stones, that had lain on the ground in the sun, could with difficulty be held in the hand; the stirrups of the saddles became so hot, that the men could not always keep their feet in them; their nails became as brittle as glass; and all the horn handles of their combs and instruments split to pieces with the intense heat. A thermometer, hung in the shade at the back of a tree, rose to $132^{\circ} \mathrm{Fahr}$., and in the sun to $157^{\circ}$ ! Only one living creature was observed: the wonder is, that any should be found in such a glowing region; but, perched on the highest and most exposed points of the rucks, where it was too hot to bear the hand for long, sat a beautiful little pigeon, with a long crest, the geophays plumifera of Gould, seeming to find enjoyment in the heat which had driven all else living away.

The general opinion as to the cause of the hot wind is, that it becomes greatly heated in passing over the burning deserts just described; and I think the theory is so rational and sufficient to account for the effect:, that no other need be sought for. The great proof of its correctness is, that the hot winds invariably blow from the interior to the colonies affected by them. In Port Phillip (now Victoria) they always blow from the north, and indeed I do not remember a north wind that was not a hot one.

We could always tell en rising in a morning, and sometimes before we left our beds, if the wind was in the north, even if we could not feel the heut. The sky, though generally free from clouds, wears a hard leaden aspect; and though at first there may be only a rentle breeze, yet it soon increases in inteusity until it blows a perfect gale, driving the dust in clouds, while the sky has deepened into a lurid tint, and the sun has a coppery appearance. Every effort of course is made by those who have experienced the effects of these winds, to close all doors and windows, and every crevice that would admit a breath, in order to husband as lone as possible the cool air which the house contains. In small houses the temperature within and without doors soon assimilates, while in larger oncs the air can be maintained cool the whole day.

As the day advances, the heat of course increases, and the thermometer soon reaches $80^{\circ}$, but it still keeps rising until $82^{\circ}, 84^{\circ}, 86^{\circ}$, and sometimes $88^{\circ}$ and $90^{\circ}$ is attained; and this is within the house, and free from every breath of hot air. Out of doors in the shade the thermometer ranges from $90^{\circ}$ to $105^{\circ}$, and sometimes higher; and I have known one instance in which it rose on a south wall (the cool quarter) in the shade, and within three miles of the sea, to $110^{\circ} !$ !

During the summer senson, rarely a week passes without one or two days of hot wind. Sometimes it blows for two days together; and on one occasion I experienced it without the slightest intermission for five consecutive days. I was told by a medical man in Melbourne, that onc day more would have "laid half the people in Melbourne on their backs". The effects upon the human frame are, as may be imagined, extremely depressing; all energy is gone, onc feels utterly exhausted, and gasps for breath like a fish out of water; but it is in vain that one opens a window to admit a little air to keep off the feeling of suffocation; a blast rushes in as hot as if it had just traversed a furnace, and one is quickly glad to close the window. Night draws nigh, and the wind generally changes at night; yet still it rushes on in the same riolent monotonous manner. Suddenly there is a lull : one hastens to open the door. The hot wind has ceased; and in two minutes, sometimes less, 